\title{
Kamu Çalışanlarının Kariyer Memnuniyetlerinin İş Doyumu Üzerine Etkisi
}

\author{
Perihan GöZÜM*
}

Ardahan Üniversitesi

\section{Öz}

$\mathrm{Bu}$ araștırmanın amacı kamu çalışanlarının kariyer memnuniyetlerinin iş doyumu üzerine etkisinin olup olmadığının belirlenmesidir. $\mathrm{Bu}$ amaçla yapılan anket çalışmasıyla bazı değişkenlere bağlı olarak depresyon eğilim etkileri incelenmeye çalışılmıştır. Araştırma verilerinin analizinde betimsel istatistikler olan aritmetik ortalama, frekans, standart sapma ve yüzde değerlerine bakılmıştır. Bu çalışma için parametrik analizlerin yapılıp yapılmayacağını belirlemek için öncelikle ölçek verilerinin normal dağılım gösterip göstermediğine bakılmıştır. Kamu çalışanlarının kariyer memnuniyeti ve iş doyumu ölçeklerine verdikleri cevaplara göre elde edilen ortalama puanlar ve standart sapma değerleri kariyer memnuniyeti ölçeği genel ortalama puanlarına göre araştırmaya katılan kamu çalışanlarının kariyer memnuniyeti düzeyinin orta seviyede olduğunu söyleyebiliriz. Kamu çalıșanlarının iș doyumu düzeylerinin de orta seviyede olduğunu söyleyebiliriz. İş doyumu ölçeğinin tüm alt boyutlarında da birbirine yakın değerler ile orta düzeyde bir iş doyumu olduğu görülmektedir. Kamu çalışanlarının iş doyumlarına bakıldığında ise kadın çalışanların iş doyumu düzeylerinin erkek çalışanlara göre anlamlı bir şekilde daha yüksek olduğu görülmüştür. Alt boyutlara bakıldığında da; ücret ve diğer haklar ve ödemeler konusunda kadın çalışanların düzeylerinin erkek çalışanlara göre daha yüksek olduğu, yönetici boyutunda kadın çalışanların düzeylerinin erkek çalışanlara göre daha yüksek olduğu, takdir ve ödüller boyutunda yine kadın çalışanların düzeylerinin erkek çalışanlara göre daha yüksek olduğu ve iş arkadaşları boyutunda da kadın çalışanların düzeylerinin erkek çalışanlara göre daha yüksek olduğu belirlenmiștir. Kamu çalışanlarının kariyer memnuniyeti ve iş doyumu düzeylerini eğitim durumu değişkenine göre değerlendirdiğimiz Tek Yönlü Anova testi analiz sonuçlarına göre iş doyumu ölçeğinin iş arkadaşları boyutu için lisansüstü eğitim mezunu olan kamu çalışanlarının düzeylerinin lise ve önceki eğitim mezunu olan çalışanlara göre anlamlı bir şekilde daha yüksek olduğu görülmüştür.

\section{Anahtar Kelimeler}

Kamu Çalışanları, Kariyer Memnuniyeti, İs Doyumu.

* Dr., Ardahan Üniversitesi, Çıldır MYO, HukukBölümü, perihangozum@gmail.com, ORCiD: 0000-0003-1174-8500 


\title{
The Effect of Civil Servants' Career Satisfaction on Their Job Satisfaction
}

\begin{abstract}
The aim of this study was to determine whether civil servants' career satisfaction has an impact on their job satisfaction or not. For this purpose, depression tendency effects depending on certain variables were examined through survey research. Descriptive statistics such as arithmetic mean, frequency, standard deviation, and percentage values were used in the analysis of the research data. In order to determine whether parametric analysis would be performed for this study or not, it was examined whether the distribution of the scale data was normal. According to the mean scores derived from the civil servants' responses to the career satisfaction and job satisfaction scales, standard deviation values, and average mean scores of career satisfaction scales, career satisfaction levels of the civil servants who participated in the study were at a moderate level. Job satisfaction levels of the civil servants were also found to be at a moderate level. Close values and a moderate level of job satisfaction were observed in all sub-dimensions of the job satisfaction scale. Regarding job satisfaction of civil servants, female employees' job satisfaction levels were significantly higher than male employees. It was determined that in terms of wages and other rights sub-dimension, levels of female employees were higher than male employees, in the management sub-dimension, levels of female employees were higher than their male counterparts, levels of female employees were higher than male employees in recognition and awards sub-dimension, and levels of female employees were higher than male employees in the colleagues sub-dimension. According to the results of the One-Way ANOVA analysis, in which career and job satisfaction levels of civil servants were evaluated according to educational background variable, for the colleagues sub-dimension of the job satisfaction scale, civil servants with a graduate degree had significantly higher levels of job satisfaction than those with high school level education or lower.
\end{abstract}

\section{Keywords}

Career Satisfaction, Civil Servant, Job Satisfaction.

\section{Extended Abstract}

There are studies in many areas where different variables are used on job satisfaction. In these studies, it has been tried to reveal whether the work performance and work motivation of the employees have positive or negative effects on job satisfaction.In the same way, the issue of career satisfaction is also a subject on which much researches have been done. The study titled the effect of career satisfaction of public employees on job satisfaction is original research since it has not been studied before.The aim of this study is to investigate whether career satisfaction has a positive or negative effect on job satisfaction in the context of public employees and to try to reveal the results of this. Especially in a global context, today, when the Covid 19 pandemic is effective, as a result of the evolution of old normals into extraordinary conditions and practices, many public institutions in our country have switched to remote, rotating, or flexible working hours. In the context of the research topic, especially the psychological state of the public personnel and working conditions caused by the pandemic is important in terms of their reflection on the results of the research. The results of the research will contribute to future studies. 


\section{Methodology and Data}

A questionnaire was applied to the participants in the study. In addition to seven demographic questions, a voluntary consent form was also created in the study. It is hoped that the career satisfaction scale in the study will be beneficial for future research in the Turkish organizational behavior literature.In this study, the Career Satisfaction Scale developed by Greenhaus, Parasuraman, and Wormly (1990), which is frequently used to measure career satisfaction, was used. The job satisfaction scale is adapted from Yelboğa's (2009) study. After explaining the purpose of the research to them and obtaining their consent, data collection forms will be filled in by face-to-face interviews with public employees (following the social distance and mask rule due to the Covid 19 outbreak). In addition, it was applied by explaining that public employees write only their own information and not be influenced by each other. The universe of this research consisted of a total of 202 public personnel, 91 women and 111 men, working in the General Directorate of Post Telegraph Telephone (PTT) in Ankara. All personnel were selected by random method during the Covid 19 epidemic period and within the scope of epidemic measures in December 2020 and formed the universe of the study on a voluntary basis.

\section{Statistical Analysis and Results}

SPSS 21.0 program was used for the analysis of the data collected in the research.In the analysis of the research data, descriptive statistics such as arithmetic mean, frequency, standard deviation, and percentage values were examined. In order to determine whether parametric analyzes will be performed for this study, it was first examined whether the scale data showed a normal distribution. We can say that the job satisfaction level of public employees is also at a medium level. It is seen that there is a moderate level of job satisfaction with close values in all sub-dimensions of the job satisfaction scale. When the job satisfaction of public employees is examined, it is seen that the job satisfaction levels of female employees are significantly higher than male employees. When we look at the sub-dimensions; It has been observed that the levels of female employees are higher than male employees in terms of wages and other rights and payments. In the managerial dimension, the level of female employees was higher than that of male employees. Moreover; It has been determined that the level of female employees in the dimension of appreciation and rewards is higher than that of male employees, and the levels of female employees are higher than male employees in the dimension of co-workers.According to the results of the One-Way Anova test analysis, in which we evaluated the career satisfaction and job satisfaction levels of public employees according to the education level variable, it was seen that the levels of public employees who graduated from postgraduate education were significantly higher for the co-workers' dimension of the job satisfaction scale compared to those who graduated from high school and previous education. 


\section{Conclusion}

It is seen that there is a moderate level of job satisfaction with close values in all sub-dimensions of the job satisfaction scale. According to the correlation analysis conducted to determine the relationship between career satisfaction and job satisfaction levels of public employees, it is seen that there is a weak positive relationship between the level of career satisfaction and job satisfaction levels of public employees. Looking at the sub-dimensions of the job satisfaction scale; A very weak positive relationship between career satisfaction and wage, other benefits and payments dimension, a weak positive relationship in terms of promotion, a very weak positive relationship in terms of manager dimension, a weak positive relationship in terms of appreciation and rewards dimension, a very weak positive relationship in terms of nature of work and lastly there is a weak positive relationship in terms of communication dimension. According to the results of the T-test analysis, in which we evaluated the career satisfaction and job satisfaction levels of public employees according to the gender variable, there was no significant difference between female and male participants in the career satisfaction scale. When the job satisfaction of public employees is examined, it is seen that the job satisfaction levels of female employees are significantly higher than male employees. Looking at the sub-dimensions; In terms of wages and other rights and payments, the level of female employees is higher than male employees, the level of female employees in the manager dimension is higher than male employees, the level of female employees is higher than male employees in the dimension of appreciation and rewards, and the level of female employees in the dimension of colleagues is also higher than male employees. According to the results of the One-Way Anova test analysis, in which we evaluated the career satisfaction and job satisfaction levels of public employees according to the age variable, there were significant differences between age groups in the career satisfaction and job satisfaction levels of public employees. In the career satisfaction scale, it has been observed that the levels of employees in the 24-29 age group and those in the 36-40 age group are significantly higher than those over the age of 41 . Likewise, in the job satisfaction scale, the levels of employees in the 24-29 age group and those in the 36-40 age group were found to be significantly higher than those of the employees over the age of 41. According to these data, we can say that the career satisfaction and job satisfaction levels of the young age groups are higher than those of the employees over the age of 40 . When the job satisfaction scale is examined, it is seen that the levels of public employees with a service period of 2-5 years are significantly higher than those of employees with a service period of 16 years or more. When the sub-dimensions of the job satisfaction scale are examined, it is seen that the level of public employees with a service period of 2-5 years and employees with a service period of 11-15 years for the promotion dimension are significantly higher than the group with a service period of 16 years and above.In terms of operating procedures, the level of public employees 
with 0-1 years of service and employees with 2-5 years of service was significantly higher than the group with 16 years or more of service.According to the results of the One Way Anova test, in which we evaluated the career satisfaction and job satisfaction levels of public employees in terms of the leisure time variable, the career satisfaction levels of public employees who say they read books in their spare time are found to be significantly higher than those who say they go to entertainment venues in their spare time.According to the results of the One-Way Anova test analysis, in which we evaluated the career satisfaction and job satisfaction levels of public employees according to the education level variable, it was seen that the levels of public employees who graduated from postgraduate education were significantly higher for the co-workers' dimension of the job satisfaction scale compared to those who graduated from high school and previous education. 


\section{Giriş}

Kariyer kelimesi Türkçe' ye İngilizce "Career", Fransızca "Carrierre" kelimelerinden gelmektedir. Fransızca da "yarış yolu", İngilizce de ise "meslek" anlamına gelen kariyer kelimesi günümüzde bir bireyin meslek hayatı boyunca kaydettiği aşamaları, ilerlemeleri ifade etmektedir. Kariyer kavramı için dört farklı tanımdan bahsedilebilir. İlki kariyeri işyerinde ilerleme olarak (terfiler, yükselmeler gibi); ikincisi, meslek açıdan başka bir ifadeyle belli bir meslek alanında (doktor, akademisyen, avukat)ilerleme olarak; üçüncüsü, yaşam boyu devam edecek işler dizisi ve işlerin bütünü olarak; dördüncüsü ise çalışma hayatında üstlenilen rol ve deneyimler olarak tanımlanmaktadır(Çetin, 2009: 400; Mutlu, 2020:4).Kariyer memnuniyeti, bireylerin kariyerinin öznel ve nesnel yönlerini oluşturan faktörlerden sağladığı doyumu ifade ettiği gibi ayrıca kariyer memnuniyetinde bireyin içsel ve dışsal yönleri objektif ve subjektif boyutlar olarak ele alınmaktadır. Objektif boyutlar bireyin çalışma ve çabalarının gelir düzeyi (maaş), yükselme (terfi), iş ortamı gibi yönlerinin tatminini ifade eder. (Judge et al., 1994). Bireylerin çalışma yaşamında elde ettiği tecrübelerin sonucunda ortaya çıkan olumlu psikolojik ya da iş ile ilgili sonuç veya başarılar şeklinde tanımlamaktadır. Kariyer memnuniyeti ile ilgili yapılan çalışmaların önemli bir kısmı Vroom'un beklenti kuramı ile kişi-çevre uyumu teorisine dayanmaktadır. Vroom'un beklenti kuramı, bireyin kariyer memnuniyeti ile ilgili bazı açıklamalar getirmektedir. Beklenti kuramına göre birey, zevklerini artırma ve sıkıntılarından kaçınma arzusu içerisindedir. Birey, işinden ve işyerindeki konumundan zevk alıyorsa yüksek düzeyde kariyer memnuniyetine sahip olacaktır (Çankaya, 2020: 1788-1789). Kariyer memnuniyetini etkileyen faktörler üzerine yapılan çalışmalar daha çok örgütsel düzeyde ele alınmıştır. Kariyer memnuniyetine yönelik olarak yapılan çalışmalarda oluşturulan kapsamlı modellere, bir dizi bireysel ve örgütsel değişkenler de dâhil edilmiştir. Bu çalışmalarda, bireysel düzeyde, demografik, beșeri ve motivasyon değişkenlerinin, kariyer memnuniyeti üzerinde etkisi olduğu tespit edilmiştir. Benzer şekilde örgütsel düzeyde de firma büyüklüğü, endüstri sektörü ve coğrafi konumu gibi değişkenlerin de kariyer memnuniyeti üzerinde etkileri gözlenmiştir (Boyar \& Güngörmüş, 2016: 56). Judge ve arkadaşları (1995) yaptıkları meta analiz çalışmasına göre kariyer memnuniyeti, çalışanların kariyerlerinin hem içsel hem de dışsal yönlerini oluşturan unsurlardan elde ettikleri doyumu ifade etmektedir. Dışsal (objektif) kariyer memnuniyeti ücret, terfi gibi somut ve maddi konulardaki algı ve tatmin düzeylerine karşıllk gelirken, içsel (subjektif) kariyer memnuniyeti ise 
bireylerin kariye gelişimleri ve başarılarına ilişkin öznel algı ve değerlemelerini yansıtmaktadır (Aktaş, 2014: 200). Çalışanların bulundukları kariyer basamaklarından memnun olmaları, çalışma ortamından motivasyonlarının artmasına neden olur. Kariyer memnuniyeti ise bireyin bulunduğu kariyer basamaklarından beklentilerine bağlıdır. Çalışma ortamında çalışanların bir bölümü yüksek gelir, bir bölümü yeteneklerini geliștirmek, bir bölümü ise yükselme olanakları veya huzurlu bir çalışma ortamı istemektedir. Ancak çalışanların bir bölümü ise çalışma ortamında örgütsel adaletin sağlanmasını isterler (Çelik, 2012:107). Kariyer memnuniyetinin kişinin aile yaşamından başlayarak çalıştığı işyerindeki sağlanan hizmetlerin kalitesinden, ödüllendirmeye ve işin nasıl organize edildiğine kadar birçok faktörden etkilenebileceğini belirtilmiştir. Bunların dışında, cinsiyet, bulunulan kariyer basamağı, kişilerin özellikleri, işin özellikleri, yöneticilerin tutumları, gelir seviyesi, eğitim seviyesi gibi birçok faktörün kariyer memnuniyetini etkilediği yapılan çalışmalarla ortaya konulmuştur (Lepnurm et al., 2006: 104).

İş tatmini olarak da bilinen iş doyumu, Latince "satis" kelimesinden türetilmiş olup yeterli anlamına gelmektedir. Doyum, kişisel, duygusal ve sosyal nitelikli bir kavram olup yalnızca ilgili birey tarafından hissedilerek tanımlanabilen, iç huzurunu anlatan karmaşık bir kavramdır (Șencan, 2011: 35). İs doyumu çalışma psikolojisi alanında yaygın biçimde kullanılan bir kavramdır. İş doyumunun üretkenlikle, güdülenmeyle, işe devamsızlıkla ve işe gecikmeyle (tardiness), iş kazalarıyla, psikolojik sağlıkla ve genel yaşam doyumuyla ilişkileri incelenmiş; iş doyumuna bağımlı, bağımsız, birlikte etkileșen değişken olarak çeşitli çözümlemeler uygulanmıştır (Dikmen, 1995: 116). İş doyumu kişinin işinden duyduğu hoşnutluk ya da hoşnut olmama durumudur. Tatmin duygusu ancak işin özellikleriyle, bireyin istekleri birbirine uyduğu zaman ortaya çıkmaktadır (Avşaroğlu, Deniz, \& Kahraman, 2005: 117). İş doyumu, işgörenin işini doğru yapmasını etkileyen önemli bir faktördür. İlk iş doyumu araştırmaları Birinci Dünya Savaşı yıllarında F.Taylor tarafından başlatılmıştır. Taylor'a göre az yorucu ve yüksek ücretli işler, işgörenin verimini artırmaktadır (Çarıkçı \& Oksay, 2004: 161). İş doyumunu açılamaya yönelik olarak geliştirilen kuramların birçoğu iş doyumu ile güdülenme arasındaki ilişskiyi temel almaktadır. İş doyumu ve güdülenme arasındaki iliş̧i Maslow, Herzberg, Adams ve Wroom tarafından ele alınmıștır. Maslow "íhtiyaçlar Hiyerarşisi Kuramı"nda insan ihtiyaçlarının hiyerarşik bir yapı içerisinde ortaya çıktığını, her bir ihtiyacın bir önemi olduğunu ve belli bir ölçüde karşılanması gerektiğini, karşılandığında ise doyumun yaşandığını açıklamaktadır. Wroom, iș doyumunun olușmasında kișilerin sosyal ihtiyaçlarının karșılanmasında farklılıkların dikkate alınması gerektiğini ifade etmektedir. Adams "Eşitlik Kuramı"nda kişilerin aynı düzeyde ve aynı koşullarda çalıştıkları kişilerle kendilerini karşılaştırdıklarını, bu doğrultuda da elde ettikleri ücret ve çeşitli olanaklar açısından eşit olup olmadıklarına bağlı olarak iş doyumu ya da 
doyumsuzluğunun geliştiğini öne sürmektedir (Eğinli, 2009: 37). Çalışanın iş doyumu arttıkça işletmelerin de verimlilikten fayda sağladıkları belirtilmektedir. Çalışan memnuniyeti arttıkça, işten ayrılma oranı azalmakta, verim ve performans yükselmektedir (Mecek, 2020: 3979; Paksoy, 2007: 140). İşinden memnun olmayanlar düşük verim ve performansla çalışarak görevlerini yerine getirmeye çalışmaktadır. Oysa örgütlerde temel amaç çalışanların performanslarından olabildiğince yararlanmaktır. Özellikle bazı sektörlerde çalışanlardan üst düzeyde verim almak yalnızca örgütlerin değil toplumun gelişmesi adına önemlidir. Eğitim sektörü bu kurumların başında gelmektedir. Geleceğin nesillerinin yetiştirildiği bu sektörde keyifle çalışan öğreticilerin genç nesillerin donanımlı yetişmesindeki katkısı tartışılamaz (Öztürk \& Şahbudak, 2015: 495). İş doyumu tükenmeyi etkileyen önemli bir etkendir. İş doyumunu yaş, cinsiyet, eğitim düzeyi gibi kişisel özelliklerin yanı sıra, yapılan işin içeriği, ücret politikası, çalışma koşulları gibi kurumsal ve çevresel etkenler etkilemektedir (Musal, Elçi \& Ergin, 1995: 3). İş doyumu ve performans arasındaki ilişki incelendiğinde iki şekilde açıklama getirilmektedir. Birincisi, kişinin işte yüksek performans göstermesi durumunda işyeri tarafından ödüllendirildiği ve bu nedenle de yüksek iş doyumuna ulaştığı açıklanabilir. İkincisi ise, yüksek iş doyumu hisseden kişinin yüksek bir performans sergilemesi söz konusu olmaktadır. Buna göre de kişi işinden doyum elde ettikçe iş performansında bir artış görülmektedir (Telman \& Ünsal, 2004: 21). İş doyumu bireyin kendi fizyolojik, psikolojik durumuna, çalışma ortamına ve koşullarına, iş arkadaşlarına ve iş gereklerine göre değişiklik gösterir. İşletmelerde kaliteyi ve verimliliği arttırmak için iş doyumu yönetimdekilerin odak noktası olmuştur (Küçük, 2014: 6). İş doyumsuzluğunun, genel yaşam doyumu, fiziksel sağlık ve ruhsal sağlık üzerine olumsuz etkilerinin yanı sıra, işe devamsızlık, işten ayrılma, iş veriminin düşmesi gibi örgütsel etkileri de olabilmektedir (Durmuş \& Günay, 2007: 140).

\section{Yöntem}

$\mathrm{Bu}$ araștırmanın evrenini Ankara ilinde bulunan Posta Telgraf Telefon (PTT) Genel Müdürlüğünde görev yapan 91 kadın 111 erkek olmak üzere toplam 202kamu personeline 2020 yılı aralık ayında Covid 19 salgını döneminde ve salgın tedbirleri kapsamında, rastgele (random) metoduyla seçilerek, gönüllülük esasına göre çalışmanın evrenini oluşturmuşlardır.

Araştırmada katılımcılara anket uygulaması yapılmıştır. Çalışmada, yedi adet demografik soru yanında, ayrıca gönüllü onam formu oluşturulmuştur. Çalışmadaki kariyer memnuniyeti ölçeğinin Türkçe örgütsel davranış yazınında gelecekteki araştırmalara faydası olacağı umulmaktadır. Bu çalışma ile kariyer memnuniyetini ölçmek üzere sıklıkla kullanılan Greenhaus, Parasuraman ve Wormly (1990) tarafından geliştirilen Kariyer Memnuniyeti Ölçeği kullanılmıştır. 5’li Likert tipi (1=Kesinlikle Katılmıyorum, 2=Katılmıyorum, 3= Ne Katılıyorum Ne Katılmıyorum, 4=Katılıyorum, 5= Kesinlikle Katılıyorum) 
olup, bu ölçek "Kariyerimde ulaştığım başarıdan memnunum." gibi 5 ifadeden oluşmaktadır. Araştırmada bu ölçeğin güvenilir bir ölçek (Cronbach's Alpha $=0.83$ ) olduğu sonucuna varılmıştır. Bir ölçeğin güvenilir olması için Cronbach's Alpha değerinin 0.70'üzerinde olması gerekir (Nunnaly, 1978), iş tatminini ölçmek üzere 36 adet sorudan oluşan bir ölçek yer almaktadır. Anket sorularının cevapları için (1= kesinlikle katılmıyorum, 5=kesinlikle katılıyorum) arasında 1-5 tipi Likert ölçeği kullanılmaktadır. Yukarıdaki modelde verilen hipotezlerin test edilmesi amaciyla geliştirilen anket formunda, iş tatmini ölçeği Yelboğa`nın (2009) çalışmasından uyarlanmaktadır. Veri toplama formları, kamu çalışanlarıyla yüz yüze görüşülerek (Covid 19 salgınından dolayı sosyal mesafe ve maske kuralına bağlı kalarak) araştırmanın amacı açıklanıp, onamları alındıktan sonra doldurulacaktır. Ayrıca kamu çalışanlarının yalnız kendi bilgilerini yazmaları, birbirlerinden etkilenmemeleri konusunda da açıklama yapılarak uygulanmıştır.

Araştırmada toplanan verilerin analizi için SPSS 21.0 programından yararlanılmıştır. Araştırma verilerinin analizinde betimsel istatistikler olan aritmetik ortalama, frekans, standart sapma ve yüzde değerlerine bakılmıştır. Bu çalışma için parametrik analizlerin yapılıp yapılmayacağını belirlemek için öncelikle ölçek verilerinin normal dağılım gösterip göstermediğine bakılmıştır. Analiz sonucunda normal dağılım grafikleri ile birlikte basıklık (kurtosis) ve çarpıklık (skewness) değerleri hesaplanmış sonuçlar aşağıda verilmiştir.

Tablo 1: Kariyer memnuniyeti ölçeği ve iș doyumu ölçeği için elde edilen çarpıklık ve basıklık değerleri.

\begin{tabular}{lll}
\hline & Skewness (Çarpıklık) & Kurtosis (Basıklık) \\
\hline Kariyer Memnuniyeti Ölçeği & $-0,042$ & 0,215 \\
\hline İş Doyumu Ölçeği & 0,384 & 2,902 \\
\hline
\end{tabular}

Normal dağılım analizi sonucunda Tablo 1'de görüldüğü gibi kariyer memnuniyeti ölçeği için çarpıklık ve basıklı değerleri -2 ile +2 arasında yer almaktadır. İş doyumu ölçeği için elde edilen çarpıklık değeri -2 ile +2 arasında olmakla birlikte basıklık değeri +2 'nin üzerinde görülmektedir. Normal dağılım grafikleri de incelenmiş ve bu sonuçlara göre kariyer memnuniyeti ve iş doyumu ölçeğinden elde edilen verilerin normal dağılım gösterdiğini söyleyebiliriz. Buna göre normal dağılım gösteren kariyer memnuniyeti ve iş doyumu ölçeğinde ikili karşılaştırmalar için bağımsız T testi, çoklu karşılaştırmalar için Tek Yönlü Anova testi ve post hoc testi olarak Tukey testi kullanılmıştır. 
Tablo 2:Kariyer memnuniyeti ve iş doyumu ölçeği için 5’li likert ölçek aralıkları.

\begin{tabular}{clc}
\hline Ağırlık & Seçenek & Sinırlar \\
\hline 1 & Kesinlikle katılmıyorum & $1,00-1,80$ \\
\hline 2 & Katılmıyorum & $1,81-2,60$ \\
\hline 3 & Ne katılıyorum ne katılmıyorum & $2,61-3,40$ \\
\hline 4 & Katılıyorum & $3,41-4,20$ \\
\hline 5 & Kesinlikle katılıyorum & $4,21-5,00$ \\
\hline
\end{tabular}

Araştırmaya katılan kamu çalışanlarının kariyer memnuniyeti ve iş doyumu düzeylerini belirlemek için kullanılan ankette 5'li likert tipi ölçek kullanılmış olup elde edilen ortalama değerlerin yorumlanmasında kullanılacak ölçek aralıkları aşağıdaki Tablo 2'de verilmiştir.

\section{Analiz ve Bulgular}

Tablo 3: Örneklem grubuna ait demografik bilgiler.

\begin{tabular}{|c|c|c|c|}
\hline & & $\mathrm{f}$ & $\%$ \\
\hline \multirow{4}{*}{ Yaşınız } & $24-29$ & 67 & 33,2 \\
\hline & $30-35$ & 72 & 35,6 \\
\hline & $36-40$ & 35 & 17,3 \\
\hline & 41 ve üzeri & 28 & 13,9 \\
\hline \multirow{2}{*}{ Cinsiyetiniz } & Kadın & 91 & 45,0 \\
\hline & Erkek & 111 & 55,0 \\
\hline \multirow{5}{*}{ Kurumdaki hizmet süreniz } & $0-1$ yll & 18 & 8,9 \\
\hline & $2-5$ yll & 96 & 47,5 \\
\hline & 6-10 yıl & 42 & 20,8 \\
\hline & $11-15 \mathrm{yll}$ & 26 & 12,9 \\
\hline & 16 yıl ve üzeri & 20 & 9,9 \\
\hline \multirow{4}{*}{$\begin{array}{l}\text { Boş zamanlarınızda ne yapmayı } \\
\text { tercih edersiniz? }\end{array}$} & Kitap okurum & 77 & 38,1 \\
\hline & Sinemaya giderim & 37 & 18,3 \\
\hline & Tarihi yerleri gezerim & 41 & 20,3 \\
\hline & Eğlence mekânlarına giderim & 47 & 23,3 \\
\hline \multirow{4}{*}{ Kadronuz } & Sözleşmeli & 124 & 61,4 \\
\hline & Memur / Uzman & 41 & 20,3 \\
\hline & Şef & 18 & 8,9 \\
\hline & Müdür / Üst düzey yönetici & 19 & 9,4 \\
\hline \multirow{4}{*}{$\begin{array}{l}\text { Günlük hayatta kendinizi nasıl } \\
\text { tanımlarsınız? }\end{array}$} & Sessiz sakin & 56 & 27,7 \\
\hline & Sosyal ve dișa dönük & 89 & 44,1 \\
\hline & Hiperaktif (hareketli) & 39 & 19,3 \\
\hline & Sinirli ve çabuk parlayan & 18 & 8,9 \\
\hline \multirow{3}{*}{ Eğitim durumu } & Lise ve öncesi & 20 & 9,9 \\
\hline & Lisans & 142 & 70,3 \\
\hline & Lisansüstü & 40 & 19,8 \\
\hline
\end{tabular}


Örneklem grubunun demografik bilgilerinin verildiği Tablo 3'e göre araştırmaya katılan kamu çalışanlarının \%33,2'si 24-29 yaş, \%35,6’sı 30-35 yaş arası olup katılımcıların çoğunun genç olduğunu söyleyebiliriz. Katılımcıların \%45,0'i kadın, \%55,0'i erkektir. Hizmet sürelerine bakıldığında \%47,5’i 2-5 yıl, \%20,8'i 6-10 yıl arası hizmete sahiptir. Araştırmaya katılan kamu çalışanlarının \%38,1'i boş zamanlarında kitap okuduğunu belirtmiş olup diğer seçenekler birbirine yakın orandadır. Katılımcıların \%61,4'ü sözleșmeli, \%20 ,3'ü memur veya uzman olarak çalışmaktadır. Günlük hayatta kendilerini nasıl tanımladıklarına bakıldığında \%44,1'i kendini sosyal ve dişa dönük olarak, \%27,7'si sessiz sakin olarak tanımlamaktadır. Araştırmaya katılanların \%70,3'lük bir çoğunluğu lisans mezunu, \%19,8'i lisansüstü eğitim mezunudur.

Tablo 4:Kamu çalışanlarının kariyer memnuniyeti ve iş doyumu ölçeğinden elde edilen ortalama puanlar ve standart sapma değerleri

\begin{tabular}{llll}
\hline & $\mathrm{N}$ & ORT & SS \\
\hline Kariyer Memnuniyeti & 202 & 2,82 & 0,42 \\
\hline İș Doyumu & 202 & 3,00 & 0,35 \\
\hline Ücret ve diğer haklar ve ödemeler & 202 & 2,87 & 0,57 \\
\hline Terfi & 202 & 2,77 & 0,78 \\
\hline Yönetici & 202 & 3,14 & 0,77 \\
\hline Takdir ve ödüller & 202 & 2,93 & 0,70 \\
\hline Faaliyet prosedürleri & 202 & 2,97 & 0,67 \\
\hline İş arkadaşları & 202 & 3,10 & 0,71 \\
\hline İşin doğası & 202 & 3,06 & 0,67 \\
\hline İletișim & 202 & 3,12 & 0,73 \\
\hline
\end{tabular}

Araştırmaya katılan kamu çalışanlarının kariyer memnuniyeti ve iş doyumu ölçeklerine verdikleri cevaplara göre elde edilen ortalama puanlar ve standart sapma değerleri Tablo 4'de verilmiştir. Kamu çalışanlarının kariyer memnuniyeti ölçeği genel ortalama puanı $\mathrm{x}=2,82 \pm 0,42$ olarak elde edilmiştir. Buna göre araştırmaya katılan kamu çalışanlarının kariyer memnuniyeti düzeyinin orta seviyede olduğunu söyleyebiliriz. İş doyumu ölçeği genel ortalama puanı $\mathrm{x}=3,00 \pm 0,35$ olarak elde edilmiştir. Buna göre kamu çalışanlarının iş doyumu düzeylerinin de orta seviyede olduğunu söyleyebiliriz. İş doyumu ölçeğinin tüm alt boyutlarında da birbirine yakın değerler ile orta düzeyde bir iş doyumu olduğu görülmektedir. 
Tablo 5:Kamu çalışanlarının kariyer memnuniyeti ile iş doyumu arasındaki ilişkiyi belirleyen Pearsonkorelasyon analizi sonuçları

\begin{tabular}{llll}
\hline Değișken (N=202) & İș Doyumu Ölçeği & $\mathrm{R}$ & $\mathrm{p}$ \\
\hline & İș Doyumu & $0,360^{* *}$ & 0,000 \\
\cline { 2 - 4 } & Ücret ve diğer haklar ve ödemeler & $0,182^{* *}$ & 0,010 \\
\cline { 2 - 4 } Kariyer Memnuniyeti & Terfi & $0,284^{* *}$ & 0,000 \\
\cline { 2 - 4 } & Yönetici & $0,177^{*}$ & 0,012 \\
\cline { 2 - 4 } & Takdir ve ödüller & $0,219^{* *}$ & 0,002 \\
\cline { 2 - 4 } & Faaliyet prosedürleri & 0,116 & 0,101 \\
\cline { 2 - 4 } & İș arkadașları & 0,012 & 0,863 \\
\cline { 2 - 4 } & İșin doğası & $0,174^{*}$ & 0,013 \\
\cline { 2 - 4 } & İletişim & $0,270^{* *}$ & 0,000 \\
\hline
\end{tabular}

** Korelasyon çift yönlü 0,01 düzeyinde anlamlıdır.

* Korelasyon çift yönlü 0,05 düzeyinde anlamlıdır.

Araştırmaya katılan kamu çalışanlarının kariyer memnuniyeti ile iş doyumu düzeyleri arasındaki ilişkiyi belirlemek için yapılan korelasyon analizinde Pearson korelasyon katsayısına bakılmış ve sonuçlar Tablo 5'de verilmiştir. Buna göre kamu çalışanlarının kariyer memnuniyeti düzeyi ile iş doyumu düzeyleri arasında pozitif yönde zayıf bir ilişki bulunduğu görülmektedir ( $\mathrm{r}=$ $0,360 \mathrm{p}=0,000$ ). İş doyumu ölçeğinin alt boyutlarına bakıldığında ise; kariyer memnuniyeti ile ücret ve diğer haklar ve ödemeler boyutu arasında pozitif yönde çok zayıf bir ilişki ( $\mathrm{r}=0,182 \mathrm{p}=0,010)$, terfi boyutu arasında pozitif yönde zayıf bir ilişki $(r=0,284 \mathrm{p}=0,000)$, yönetici boyutu arasında pozitif yönde çok zayıf bir ilişki ( $r=0,177 \mathrm{p}=0,012)$, takdir ve ödüller boyutu arasında pozitif yönde zayıf bir ilişki ( $r=0,219 \mathrm{p}=0,002)$, işin doğası boyutu arasında pozitif yönde çok zayıf bir ilişki $(r=0,174 \mathrm{p}=0,013)$ ve iletişim boyutu arasında pozitif yönde zayıf bir ilişki $(r=0,270 p=0,000)$ bulunduğu görülmektedir.

Tablo 6:Kamu çalışanlarının kariyer memnuniyeti ve iş doyumunu cinsiyet değişkenine göre karşılaştıran T Testi sonuçları

\begin{tabular}{|c|c|c|c|c|c|c|}
\hline & Cinsiyet & $\mathrm{N}$ & ORT & SS & $\mathrm{t}$ & $\mathrm{P}$ \\
\hline \multirow{2}{*}{ Kariyer Memnuniyeti } & Kadın & 91 & 2,86 & 0,42 & \multirow{2}{*}{1,057} & \multirow{2}{*}{0,292} \\
\hline & Erkek & 111 & 2,80 & 0,43 & & \\
\hline \multirow{2}{*}{ İș Doyumu } & Kadın & 91 & 3,07 & 0,37 & \multirow{2}{*}{2,679} & \multirow{2}{*}{$0,008 * *$} \\
\hline & Erkek & 111 & 2,94 & 0,33 & & \\
\hline
\end{tabular}




\begin{tabular}{|c|c|c|c|c|c|c|}
\hline \multirow{2}{*}{$\begin{array}{l}\text { Ücret ve diğer haklar } \\
\text { ve ödemeler }\end{array}$} & Kadın & 91 & 2,99 & 0,64 & \multirow{2}{*}{2,891} & \multirow{2}{*}{$0,004^{* *}$} \\
\hline & Erkek & 111 & 2,76 & 0,48 & & \\
\hline \multirow{2}{*}{ Terfi } & Kadın & 91 & 2,75 & 0,79 & \multirow{2}{*}{$-0,410$} & \multirow{2}{*}{0,682} \\
\hline & Erkek & 111 & 2,79 & 0,78 & & \\
\hline \multirow{2}{*}{ Yönetici } & Kadın & 91 & 3,29 & 0,84 & \multirow{2}{*}{2,592} & \multirow{2}{*}{0,010 ** } \\
\hline & Erkek & 111 & 3,01 & 0,68 & & \\
\hline \multirow{2}{*}{ Takdir ve ödüller } & Kadın & 91 & 3,05 & 0,70 & \multirow{2}{*}{2,195} & \multirow{2}{*}{$0,029 * *$} \\
\hline & Erkek & 111 & 2,83 & 0,69 & & \\
\hline \multirow{2}{*}{ Faaliyet prosedürleri } & Kadın & 91 & 2,91 & 0,68 & \multirow{2}{*}{$-1,265$} & \multirow{2}{*}{0,207} \\
\hline & Erkek & 111 & 3,03 & 0,67 & & \\
\hline \multirow{2}{*}{ İş arkadaşları } & Kadın & 91 & 3,26 & 0,72 & \multirow{2}{*}{2,818} & \multirow{2}{*}{$0,005 * *$} \\
\hline & Erkek & 111 & 2,98 & 0,68 & & \\
\hline \multirow{2}{*}{ İşin doğası } & Kadın & 91 & 3,12 & 0,66 & \multirow{2}{*}{1,236} & \multirow{2}{*}{0,218} \\
\hline & Erkek & 111 & 3,01 & 0,68 & & \\
\hline \multirow{2}{*}{ İletişim } & Kadın & 91 & 3,17 & 0,70 & \multirow{2}{*}{0,982} & \multirow{2}{*}{0,327} \\
\hline & Erkek & 111 & 3,07 & 0,74 & & \\
\hline
\end{tabular}

** $P<0,05$ düzeyinde anlamlı fark ifade etmektedir.

Araştırmaya katılan kamu çalışanlarının kariyer memnuniyeti ve iş doyumu düzeylerini cinsiyet değişkenine göre değerlendirdiğimiz T testi analiz sonuçları Tablo 6'da verilmiştir. Yapılan T testi sonuçlarına göre kariyer memnuniyeti ölçeğinde kadın ve erkek katılımcılar arasında anlamlı bir fark görülmemiştir. Kamu çalışanlarının iş doyumlarına bakıldığında ise kadın çalışanların iş doyumu düzeylerinin $(x=3,07 \pm 0,37)$ erkek çalışanlara göre $(x=2,94 \pm 0,33)$ anlamlı bir şekilde daha yüksek olduğu görülmüştür. Alt boyutlara bakıldığında da; ücret ve diğer haklar ve ödemeler konusunda kadın çalışanların düzeylerinin $(x=2,99 \pm 0,64)$ erkek çalışanlara göre $(x=2,76 \pm 0,48)$ daha yüksek olduğu, yönetici boyutunda kadın çalışanların düzeylerinin $(x=3,29 \pm 0,84)$ erkek çalışanlara göre $(x=3,01 \pm 0,68)$ daha yüksek olduğu, takdir ve ödüller boyutunda yine kadın çalışanların düzeylerinin $(x=3,05 \pm 0,70)$ erkek çalışanlara göre $(x=2,83 \pm 0,69)$ daha yüksek olduğu ve iş arkadaşları boyutunda da kadın çalışanların düzeylerinin $(x=3,26 \pm 0,72)$ erkek çalışanlara göre $(x=2,98 \pm 0,68)$ daha yüksek olduğu belirlenmiștir $(\mathrm{p}<0,05)$. 
Tablo 7:Kamu çalışanlarının kariyer memnuniyeti ve iş doyumunu yaş değișkenine göre karşılaştıran tek yönlü anova testi sonuçları

\begin{tabular}{|c|c|c|c|c|c|c|c|}
\hline & Yaș & $\mathrm{N}$ & ORT & SS & $\mathrm{F}$ & $\mathrm{P}$ & Fark \\
\hline \multirow{4}{*}{$\begin{array}{l}\text { Kariyer } \\
\text { Memnuniyeti }\end{array}$} & $24-29$ & 67 & 2,89 & 0,44 & \multirow{4}{*}{4,413} & \multirow{4}{*}{$0,005^{* *}$} & \multirow{4}{*}{$\begin{array}{l}1-4 \\
3-4\end{array}$} \\
\hline & $30-35$ & 72 & 2,76 & 0,42 & & & \\
\hline & $36-40$ & 35 & 2,97 & 0,43 & & & \\
\hline & 41 ve üzeri & 28 & 2,64 & 0,29 & & & \\
\hline \multirow{4}{*}{ İş Doyumu } & $24-29$ & 67 & 3,05 & 0,45 & \multirow{4}{*}{3,247} & \multirow{4}{*}{$0,023^{* *}$} & \multirow{4}{*}{$\begin{array}{l}1-4 \\
3-4\end{array}$} \\
\hline & $30-35$ & 72 & 2,96 & 0,25 & & & \\
\hline & $36-40$ & 35 & 3,08 & 0,26 & & & \\
\hline & 41 ve üzeri & 28 & 2,84 & 0,36 & & & \\
\hline \multirow{4}{*}{$\begin{array}{l}\text { Ücret ve diğer } \\
\text { haklar ve } \\
\text { ödemeler }\end{array}$} & 24-29 & 67 & 2,93 & 0,69 & \multirow{4}{*}{1,004} & \multirow{4}{*}{0,392} & \\
\hline & $30-35$ & 72 & 2,88 & 0,54 & & & \\
\hline & $36-40$ & 35 & 2,86 & 0,45 & & & \\
\hline & 41 ve üzeri & 28 & 2,70 & 0,44 & & & \\
\hline \multirow{4}{*}{ Terfi } & 24-29 & 67 & 2,84 & 0,75 & \multirow{4}{*}{2,467} & \multirow{4}{*}{0,063} & \\
\hline & $30-35$ & 72 & 2,71 & 0,78 & & & \\
\hline & $36-40$ & 35 & 3,00 & 0,73 & & & \\
\hline & 41 ve üzeri & 28 & 2,50 & 0,89 & & & \\
\hline \multirow{4}{*}{ Yönetici } & $24-29$ & 67 & 3,24 & 0,87 & \multirow{4}{*}{0,713} & \multirow{4}{*}{0,545} & \\
\hline & $30-35$ & 72 & 3,12 & 0,71 & & & \\
\hline & $36-40$ & 35 & 3,05 & 0,74 & & & \\
\hline & 41 ve üzeri & 28 & 3,04 & 0,70 & & & \\
\hline \multirow{4}{*}{ Takdir ve ödüller } & 24-29 & 67 & 3,00 & 0,70 & \multirow{4}{*}{2,245} & \multirow{4}{*}{0,084} & \\
\hline & $30-35$ & 72 & 2,86 & 0,69 & & & \\
\hline & $36-40$ & 35 & 3,11 & 0,76 & & & \\
\hline & 41 ve üzeri & 28 & 2,71 & 0,60 & & & \\
\hline \multirow{4}{*}{$\begin{array}{l}\text { Faaliyet } \\
\text { prosedürleri }\end{array}$} & $24-29$ & 67 & 2,99 & 0,70 & \multirow{4}{*}{1,904} & \multirow{4}{*}{0,130} & \\
\hline & $30-35$ & 72 & 3,01 & 0,61 & & & \\
\hline & $36-40$ & 35 & 3,09 & 0,65 & & & \\
\hline & 41 ve üzeri & 28 & 2,71 & 0,76 & & & \\
\hline \multirow{4}{*}{ İş arkadaşları } & $24-29$ & 67 & 3,14 & 0,70 & \multirow{4}{*}{0,365} & & \\
\hline & $30-35$ & 72 & 3,04 & 0,78 & & 0778 & \\
\hline & $36-40$ & 35 & 3,09 & 0,56 & & $0,7 / 8$ & \\
\hline & 41 ve üzeri & 28 & 3,19 & 0,74 & & & \\
\hline & $24-29$ & 67 & 3,03 & 0,66 & & & \\
\hline & $30-35$ & 72 & 3,01 & 0,65 & & & \\
\hline Işin dogası & $36-40$ & 35 & 3,24 & 0,60 & 1,072 & 0,362 & \\
\hline & 41 ve üzeri & 28 & 3,03 & 0,80 & & & \\
\hline & $24-29$ & 67 & 3,21 & 0,78 & & & \\
\hline İlicim & $30-35$ & 72 & 3,07 & 0,69 & 1648 & 0180 & \\
\hline lletışım & $36-40$ & 35 & 3,22 & 0,62 & 1,648 & 0,180 & \\
\hline & 41 ve üzeri & 28 & 2,89 & 0,79 & & & \\
\hline
\end{tabular}


Araştırmaya katılan kamu çalışanlarının kariyer memnuniyeti ve iş doyumu düzeylerini yaş değişkenine göre değerlendirdiğimiz Tek Yönlü Anova testi analiz sonuçları Tablo 7'de verilmiştir. Yapılan tek yönlü anova testi sonuçlarına göre kamu çalışanlarının kariyer memnuniyeti ve iş doyumu düzeylerinde yaş grupları arasında anlamlı farklar görülmüştür. Kariyer memnuniyeti ölçeğinde 24-29 yaş grubu çalışanların ( $x=2,89 \pm 0,44)$ ve 36-40 yaş grubu çalışanların $(\mathrm{x}=2,97 \pm 0,43)$ düzeylerinin 41 yaş üzerindeki çalışanlara göre $(x=2,64 \pm 0,29)$ anlamlı bir şekilde daha yüksek olduğu görülmüştür $(\mathrm{p}<0,05)$. Aynı şekilde iş doyumu ölçeğinde de 24-29 yaş grubu çalışanların $(x=3,05 \pm 0,45)$ ve $36-40$ yaş grubu çalışanların $(x=3,08 \pm 0,26)$ düzeylerinin 41 yaş üzerindeki çalışanlara göre $(x=2,84 \pm 0,36)$ anlamlı bir şekilde daha yüksek olduğu görülmüştür $(\mathrm{p}<0,05)$. Elde edilen bu verilere göre genç yaş gruplarındaki kamu çalışanlarının kariyer memnuniyeti ve iş doyumu düzeylerinin 40 yaş üzeri çalışanlara göre daha yüksek olduğunu söyleyebiliriz.

Tablo 8:Kamu çalışanlarının kariyer memnuniyeti ve iş doyumunu hizmet süresi değişkenine göre karşılaştıran tek yönlü anova testi sonuçları

\begin{tabular}{|c|c|c|c|c|c|c|c|}
\hline & Hizmet süresi & $\mathrm{N}$ & ORT & SS & $\mathrm{F}$ & $\mathrm{P}$ & Fark \\
\hline \multirow{5}{*}{$\begin{array}{l}\text { Kariyer } \\
\text { Memnuniyeti }\end{array}$} & 0-1 yll & 18 & 2,78 & 0,60 & \multirow{5}{*}{1,920} & \multirow{5}{*}{0,109} & \\
\hline & $2-5$ yil & 96 & 2,87 & 0,40 & & & \\
\hline & 6-10 yil & 42 & 2,79 & 0,43 & & & \\
\hline & $11-15 \mathrm{yll}$ & 26 & 2,88 & 0,34 & & & \\
\hline & 16 yll ve üzeri & 20 & 2,61 & 0,39 & & & \\
\hline \multirow{5}{*}{ İş Doyumu } & 0-1 yll & 18 & 3,07 & 0,59 & \multirow{5}{*}{2,397} & \multirow{5}{*}{$0,033^{* *}$} & \multirow{5}{*}{$2-5$} \\
\hline & $2-5$ yil & 96 & 3,02 & 0,35 & & & \\
\hline & 6-10 yil & 42 & 2,99 & 0,25 & & & \\
\hline & $11-15 \mathrm{yll}$ & 26 & 3,03 & 0,17 & & & \\
\hline & 16 yll ve üzeri & 20 & 2,78 & 0,41 & & & \\
\hline \multirow{5}{*}{$\begin{array}{l}\text { Ücret ve diğer } \\
\text { haklar ve } \\
\text { ödemeler }\end{array}$} & 0-1 yl & 18 & 3,05 & 0,69 & \multirow{5}{*}{1,984} & \multirow{5}{*}{0,098} & \\
\hline & $2-5$ yil & 96 & 2,92 & 0,61 & & & \\
\hline & 6-10 yil & 42 & 2,79 & 0,49 & & & \\
\hline & $11-15$ yil & 26 & 2,86 & 0,43 & & & \\
\hline & 16 yll ve üzeri & 20 & 2,60 & 0,53 & & & \\
\hline \multirow{5}{*}{ Terfi } & 0-1 yl & 18 & 2,82 & 0,89 & \multirow{5}{*}{2,955} & \multirow{5}{*}{$0,021^{* *}$} & \multirow{5}{*}{$\begin{array}{l}2-5 \\
4-5\end{array}$} \\
\hline & 2-5 yll & 96 & 2,87 & 0,70 & & & \\
\hline & 6-10 yll & 42 & 2,63 & 0,83 & & & \\
\hline & $11-15 \mathrm{yll}$ & 26 & 2,97 & 0,76 & & & \\
\hline & 16 yll ve üzeri & 20 & 2,31 & 0,87 & & & \\
\hline \multirow{5}{*}{ Yönetici } & 0-1 yll & 18 & 3,18 & 1,06 & \multirow{5}{*}{0,376} & \multirow{5}{*}{0,826} & \\
\hline & $2-5$ yll & 96 & 3,15 & 0,81 & & & \\
\hline & 6-10 yil & 42 & 3,21 & 0,65 & & & \\
\hline & $11-15 \mathrm{yll}$ & 26 & 2,99 & 0,65 & & & \\
\hline & 16 yll ve üzeri & 20 & 3,08 & 0,68 & & & \\
\hline
\end{tabular}




\begin{tabular}{|c|c|c|c|c|c|c|c|}
\hline & Hizmet süresi & $\mathrm{N}$ & ORT & SS & $\mathrm{F}$ & $\mathrm{P}$ & Fark \\
\hline \multirow{5}{*}{ Takdir ve ödüller } & $0-1$ yıl & 18 & 2,82 & 0,80 & \multirow{5}{*}{1,379} & \multirow{5}{*}{0,243} & \\
\hline & $2-5$ yil & 96 & 2,99 & 0,66 & & & \\
\hline & 6-10 yil & 42 & 2,96 & 0,77 & & & \\
\hline & $11-15$ yll & 26 & 2,94 & 0,66 & & & \\
\hline & 16 yıl ve üzeri & 20 & 2,61 & 0,68 & & & \\
\hline \multirow{5}{*}{$\begin{array}{l}\text { Faaliyet } \\
\text { prosedürleri }\end{array}$} & $0-1$ yll & 18 & 3,18 & 0,83 & \multirow{5}{*}{2,430} & \multirow{5}{*}{$0,049 * *$} & \multirow{5}{*}{$\begin{array}{l}1-5 \\
2-5\end{array}$} \\
\hline & $2-5$ yil & 96 & 3,03 & 0,62 & & & \\
\hline & 6-10 yıl & 42 & 2,93 & 0,61 & & & \\
\hline & $11-15$ yll & 26 & 3,00 & 0,71 & & & \\
\hline & 16 yıl ve üzeri & 20 & 2,58 & 0,75 & & & \\
\hline \multirow{5}{*}{ İş arkadaşları } & $0-1$ yll & 18 & 3,26 & 0,80 & \multirow{5}{*}{0,438} & \multirow{5}{*}{0,781} & \\
\hline & $2-5$ yil & 96 & 3,04 & 0,73 & & & \\
\hline & 6-10 yıl & 42 & 3,14 & 0,71 & & & \\
\hline & $11-15$ yll & 26 & 3,14 & 0,54 & & & \\
\hline & 16 yıl ve üzeri & 20 & 3,11 & 0,76 & & & \\
\hline \multirow{5}{*}{ İşin doğası } & $0-1$ yıl & 18 & 2,96 & 0,81 & \multirow{5}{*}{0,648} & \multirow{5}{*}{0,629} & \\
\hline & $2-5$ yll & 96 & 3,02 & 0,62 & & & \\
\hline & 6-10 yıl & 42 & 3,14 & 0,64 & & & \\
\hline & $11-15$ yll & 26 & 3,19 & 0,63 & & & \\
\hline & 16 yıl ve üzeri & 20 & 3,00 & 0,87 & & & \\
\hline \multirow{5}{*}{ İletişim } & 0-1 yıl & 18 & 3,26 & 0,89 & \multirow{5}{*}{0,701} & \multirow{5}{*}{0,592} & \\
\hline & $2-5$ yll & 96 & 3,16 & 0,70 & & & \\
\hline & 6-10 yıl & 42 & 3,07 & 0,68 & & & \\
\hline & $11-15$ yll & 26 & 3,10 & 0,61 & & & \\
\hline & 16 yıl ve üzeri & 20 & 2,91 & 0,94 & & & \\
\hline
\end{tabular}

** $P<0,05$ düzeyinde anlamlı fark ifade etmektedir.

Araştırmaya katılan kamu çalışanlarının kariyer memnuniyeti ve iş doyumu düzeylerini hizmet süresi değişkenine göre değerlendirdiğimiz Tek Yönlü Anova testi analiz sonuçları Tablo 8'de verilmiştir. Yapılan tek yönlü anova testi sonuçlarına göre kamu çalışanlarının kariyer memnuniyeti düzeylerinde gruplar arasında anlamlı bir fark görülmemiştir. İş doyumu ölçeğine bakıldığında hizmet süresi 2-5 yıl arasında olan kamu çalışanlarının düzeylerinin $(x=3,02 \pm 0,35)$ hizmet süresi 16 yll ve üzeri olan çalışanlara göre $(x=2,78 \pm 0,41)$ anlamlı bir şekilde daha yüksek olduğu görülmüştür $(p<0,05)$. İş doyumu ölçeğinin alt boyutlarına bakıldığında ise terfi boyutu için hizmet süresi 2-5 yıl olan kamu çalışanlarının $(x=2,87 \pm 0,70)$ ve hizmet süresi 11-15 yıl olan çalışanların $(x=2,97 \pm 0,76)$ düzeylerinin hizmet süresi 16 yll ve üzeri olan gruba göre $(x=2,31 \pm 0,87)$ anlamlı bir şekilde daha yüksek olduğu görülmüştür $(\mathrm{p}<0,05)$.Faaliyet prosedürleri boyutunda da hizmet süresi 0-1 yıl olan kamu çalışanlarının $(\mathrm{x}=3,18 \pm 0,83)$ ve hizmet süresi 2-5 yıl olan çalışanların $(x=3,03 \pm 0,62)$ düzeylerinin hizmet süresi 16 yıl ve üzeri olan gruba göre $(x=2,58 \pm 0,75)$ anlamlı bir şekilde daha yüksek olduğu görülmüştür $(p<0,05)$. 
Tablo 9:Kamu çalışanlarının kariyer memnuniyeti ve iş doyumunu boş zaman değerlendirme değişkenine göre karşılaştıran tek yönlü anova testi sonuçları

\begin{tabular}{|c|c|c|c|c|c|c|c|}
\hline & $\begin{array}{c}\text { Boş Zaman } \\
\text { Değerlendirme }\end{array}$ & $\mathrm{N}$ & ORT & SS & $\mathrm{F}$ & $\mathrm{P}$ & Fark \\
\hline \multirow{4}{*}{$\begin{array}{l}\text { Kariyer } \\
\text { Memnuniyeti }\end{array}$} & Kitap okurum & 77 & 2,87 & 0,46 & \multirow{4}{*}{2,807} & \multirow{4}{*}{$0,041^{* *}$} & \multirow{4}{*}{$1-4$} \\
\hline & Sinemaya giderim & 37 & 2,88 & 0,40 & & & \\
\hline & Tarihi yerleri gezerim & 41 & 2,86 & 0,34 & & & \\
\hline & $\begin{array}{c}\text { Eğlence mekânlarına } \\
\text { giderim }\end{array}$ & 47 & 2,67 & 0,42 & & & \\
\hline \multirow{4}{*}{ İș Doyumu } & Kitap okurum & 77 & 3,05 & 0,42 & \multirow{4}{*}{1,217} & \multirow{4}{*}{0,305} & \\
\hline & Sinemaya giderim & 37 & 2,96 & 0,28 & & & \\
\hline & Tarihi yerleri gezerim & 41 & 2,99 & 0,25 & & & \\
\hline & $\begin{array}{c}\text { Eğlence mekânlarına } \\
\text { giderim }\end{array}$ & 47 & 2,94 & 0,36 & & & \\
\hline \multirow{4}{*}{$\begin{array}{l}\text { Ücret ve diğer } \\
\text { haklar ve } \\
\text { ödemeler }\end{array}$} & Kitap okurum & 77 & 2,92 & 0,63 & \multirow{4}{*}{0,614} & \multirow{4}{*}{0,607} & \\
\hline & Sinemaya giderim & 37 & 2,89 & 0,47 & & & \\
\hline & Tarihi yerleri gezerim & 41 & 2,81 & 0,51 & & & \\
\hline & $\begin{array}{l}\text { Eğlence mekânlarına } \\
\text { giderim }\end{array}$ & 47 & 2,80 & 0,60 & & & \\
\hline \multirow{4}{*}{ Terfi } & Kitap okurum & 77 & 2,87 & 0,81 & \multirow{4}{*}{1,754} & \multirow{4}{*}{0,157} & \\
\hline & Sinemaya giderim & 37 & 2,72 & 0,72 & & & \\
\hline & Tarihi yerleri gezerim & 41 & 2,87 & 0,83 & & & \\
\hline & $\begin{array}{c}\text { Eğlence mekânlarına } \\
\text { giderim }\end{array}$ & 47 & 2,57 & 0,72 & & & \\
\hline \multirow{4}{*}{ Yönetici } & Kitap okurum & 77 & 3,17 & 0,84 & \multirow{4}{*}{0,155} & \multirow{4}{*}{0,926} & \\
\hline & Sinemaya giderim & 37 & 3,15 & 0,64 & & & \\
\hline & Tarihi yerleri gezerim & 41 & 3,07 & 0,66 & & & \\
\hline & $\begin{array}{l}\text { Eğlence mekânlarına } \\
\text { giderim }\end{array}$ & 47 & 3,12 & 0,84 & & & \\
\hline \multirow{4}{*}{$\begin{array}{l}\text { Takdir ve } \\
\text { ödüller }\end{array}$} & Kitap okurum & 77 & 2,99 & 0,69 & \multirow{4}{*}{0,631} & \multirow{4}{*}{0,596} & \\
\hline & Sinemaya giderim & 37 & 2,80 & 0,68 & & & \\
\hline & Tarihi yerleri gezerim & 41 & 2,92 & 0,70 & & & \\
\hline & $\begin{array}{l}\text { Eğlence mekânlarına } \\
\text { giderim }\end{array}$ & 47 & 2,94 & 0,75 & & & \\
\hline \multirow{4}{*}{$\begin{array}{l}\text { Faaliyet } \\
\text { prosedürleri }\end{array}$} & Kitap okurum & 77 & 3,04 & 0,71 & \multirow{4}{*}{0,426} & \multirow{4}{*}{0,735} & \\
\hline & Sinemaya giderim & 37 & 2,94 & 0,62 & & & \\
\hline & Tarihi yerleri gezerim & 41 & 2,95 & 0,74 & & & \\
\hline & $\begin{array}{c}\text { Eğlence mekânlarına } \\
\text { giderim }\end{array}$ & 47 & 2,91 & 0,61 & & & \\
\hline \multirow{4}{*}{ İş arkadaşları } & Kitap okurum & 77 & 3,03 & 0,78 & \multirow{4}{*}{0,879} & \multirow{4}{*}{0,453} & \\
\hline & Sinemaya giderim & 37 & 3,06 & 0,50 & & & \\
\hline & Tarihi yerleri gezerim & 41 & 3,12 & 0,74 & & & \\
\hline & $\begin{array}{l}\text { Eğlence mekânlarına } \\
\text { giderim }\end{array}$ & 47 & 3,24 & 0,71 & & & \\
\hline
\end{tabular}


Kamu Çalışanlarının Kariyer Memnuniyetlerinin İș Doyumu Üzerine Etkisi

\begin{tabular}{|c|c|c|c|c|c|c|c|}
\hline \multirow{4}{*}{ İşin doğası } & Kitap okurum & 77 & 3,24 & 0,65 & \multirow{4}{*}{3,131} & \multirow{4}{*}{$0,027^{* *}$} & \multirow{4}{*}{$1-4$} \\
\hline & Sinemaya giderim & 37 & 2,93 & 0,68 & & & \\
\hline & Tarihi yerleri gezerim & 41 & 3,00 & 0,54 & & & \\
\hline & $\begin{array}{c}\text { Eğlence mekânlarına } \\
\text { giderim }\end{array}$ & 47 & 2,93 & 0,74 & & & \\
\hline \multirow{4}{*}{ İletişim } & Kitap okurum & 77 & 3,13 & 0,78 & \multirow{4}{*}{0,811} & \multirow{4}{*}{0,489} & \\
\hline & Sinemaya giderim & 37 & 3,19 & 0,66 & & & \\
\hline & Tarihi yerleri gezerim & 41 & 3,18 & 0,55 & & & \\
\hline & $\begin{array}{l}\text { Eğlence mekânlarına } \\
\text { giderim }\end{array}$ & 47 & 2,98 & 0,82 & & & \\
\hline
\end{tabular}

** $P<0,05$ düzeyinde anlamlı fark ifade etmektedir.

Araştırmaya katılan kamu çalışanlarının kariyer memnuniyeti ve iş doyumu düzeylerini boş zaman değerlendirme değişkenine göre değerlendirdiğimiz Tek Yönlü Anova testi analiz sonuçları Tablo 9'da verilmiştir. Yapılan tek yönlü anova testi sonuçlarına göre boş zamanımda kitap okurum diyen kamu çalışanlarının kariyer memnuniyeti düzeyleri $(x=2,87 \pm 0,46)$ boş zamanımda eğlence mekânlarına giderim diyen çalıșanlara göre $(x=2,67 \pm 0,42)$ anlamlı bir şekilde daha yüksek görülmüştür $(p<0,05)$. İş doyumu ölçeğinin alt boyutlarından işin doğası boyutu için de boş zamanımda kitap okurum diyen kamu çalışanlarının iş doyumu düzeyleri $(x=3,24 \pm 0,65)$ boş zamanımda eğlence mekânlarına giderim diyen çalışanlara göre $(x=2,93 \pm 0,74)$ anlamlı bir şekilde daha yüksek görülmüştür $(\mathrm{p}<0,05)$.

Tablo 10:Kamu çalışanlarının kariyer memnuniyeti ve iş doyumunu kadro değişkenine göre karşılaştıran tek yönlü anova testi sonuçları

\begin{tabular}{|c|c|c|c|c|c|c|}
\hline & Kadro & $\mathrm{N}$ & ORT & SS & F & $P$ \\
\hline \multirow{4}{*}{$\begin{array}{l}\text { Kariyer } \\
\text { Memnuniyeti }\end{array}$} & Sözleşmeli & 124 & 2,81 & 0,46 & \multirow{4}{*}{0,213} & \multirow{4}{*}{0,887} \\
\hline & Memur / Uzman & 41 & 2,86 & 0,40 & & \\
\hline & Şef & 18 & 2,86 & 0,35 & & \\
\hline & $\begin{array}{l}\text { Müdür / Üst düzey yö- } \\
\text { netici }\end{array}$ & 19 & 2,78 & 0,30 & & \\
\hline \multirow{4}{*}{ İş Doyumu } & Sözleşmeli & 124 & 3,00 & 0,40 & \multirow{4}{*}{0,839} & \multirow{4}{*}{0,474} \\
\hline & Memur / Uzman & 41 & 3,01 & 0,25 & & \\
\hline & Şef & 18 & 3,03 & 0,15 & & \\
\hline & $\begin{array}{l}\text { Müdür / Üst düzey yö- } \\
\text { netici }\end{array}$ & 19 & 2,88 & 0,30 & & \\
\hline \multirow{4}{*}{$\begin{array}{l}\text { Ücret ve diğer } \\
\text { haklar ve } \\
\text { ödemeler }\end{array}$} & Sözleşmeli & 124 & 2,89 & 0,61 & \multirow{4}{*}{0,385} & \multirow{4}{*}{0,764} \\
\hline & Memur / Uzman & 41 & 2,87 & 0,53 & & \\
\hline & Şef & 18 & 2,84 & 0,49 & & \\
\hline & $\begin{array}{l}\text { Müdür / Üst düzey yö- } \\
\text { netici }\end{array}$ & 19 & 2,74 & 0,49 & & \\
\hline
\end{tabular}




\begin{tabular}{|c|c|c|c|c|c|c|}
\hline & Kadro & $\mathrm{N}$ & ORT & SS & $\mathrm{F}$ & $\mathrm{P}$ \\
\hline \multirow{4}{*}{ Terfi } & Sözleşmeli & 124 & 2,70 & 0,79 & \multirow{4}{*}{1,012} & \multirow{4}{*}{0,388} \\
\hline & Memur / Uzman & 41 & 2,91 & 0,78 & & \\
\hline & Şef & 18 & 2,93 & 0,86 & & \\
\hline & $\begin{array}{l}\text { Müdür / Üst düzey yö- } \\
\text { netici }\end{array}$ & 19 & 2,76 & 0,71 & & \\
\hline \multirow{4}{*}{ Yönetici } & Sözleş̧meli & 124 & 3,16 & 0,85 & \multirow{4}{*}{0,473} & \multirow{4}{*}{0,701} \\
\hline & Memur / Uzman & 41 & 3,17 & 0,65 & & \\
\hline & Şef & 18 & 2,96 & 0,65 & & \\
\hline & $\begin{array}{l}\text { Müdür / Üst düzey yö- } \\
\text { netici }\end{array}$ & 19 & 3,05 & 0,54 & & \\
\hline \multirow{4}{*}{ Takdir ve ödüller } & Sözleşmeli & 124 & 2,95 & 0,70 & \multirow{4}{*}{0,220} & \multirow{4}{*}{0,883} \\
\hline & Memur / Uzman & 41 & 2,93 & 0,71 & & \\
\hline & Şef & 18 & 2,85 & 0,68 & & \\
\hline & $\begin{array}{l}\text { Müdür / Üst düzey yö- } \\
\text { netici }\end{array}$ & 19 & 2,84 & 0,73 & & \\
\hline \multirow{4}{*}{$\begin{array}{l}\text { Faaliyet } \\
\text { prosedürleri }\end{array}$} & Sözleşmeli & 124 & 2,97 & 0,68 & \multirow{4}{*}{0,248} & \multirow{4}{*}{0,062} \\
\hline & Memur / Uzman & 41 & 3,01 & 0,63 & & \\
\hline & Şef & 18 & 3,25 & 0,57 & & \\
\hline & $\begin{array}{l}\text { Müdür / Üst düzey yö- } \\
\text { netici }\end{array}$ & 19 & 2,66 & 0,75 & & \\
\hline \multirow{4}{*}{ İş arkadaşları } & Sözleșmeli & 124 & 3,16 & 0,69 & \multirow{4}{*}{0,725} & \multirow{4}{*}{0,538} \\
\hline & Memur / Uzman & 41 & 3,02 & 0,73 & & \\
\hline & Şef & 18 & 2,96 & 0,86 & & \\
\hline & $\begin{array}{l}\text { Müdür / Üst düzey yö- } \\
\text { netici }\end{array}$ & 19 & 3,04 & 0,63 & & \\
\hline \multirow{4}{*}{ İşin doğası } & Sözleşmeli & 124 & 3,06 & 0,67 & \multirow{4}{*}{1,950} & \multirow{4}{*}{0,123} \\
\hline & Memur / Uzman & 41 & 2,97 & 0,63 & & \\
\hline & Șef & 18 & 3,39 & 0,77 & & \\
\hline & $\begin{array}{l}\text { Müdür / Üst düzey yö- } \\
\text { netici }\end{array}$ & 19 & 2,93 & 0,62 & & \\
\hline \multirow{4}{*}{ İletişim } & Sözleşmeli & 124 & 3,12 & 0,78 & \multirow{4}{*}{0,413} & \multirow{4}{*}{0,744} \\
\hline & Memur / Uzman & 41 & 3,20 & 0,62 & & \\
\hline & Şef & 18 & 3,08 & 0,54 & & \\
\hline & $\begin{array}{l}\text { Müdür / Üst düzey yö- } \\
\text { netici }\end{array}$ & 19 & 2,97 & 0,78 & & \\
\hline
\end{tabular}

** $P<0,05$ düzeyinde anlamlı fark ifade etmektedir.

Araştırmaya katılan kamu çalışanlarının kariyer memnuniyeti ve iş doyumu düzeylerini kadro değişkenine göre değerlendirdiğimiz Tek Yönlü Anova testi analiz sonuçları Tablo 10 'da verilmiştir. Yapılan tek yönlü anova testi sonuçlarına göre farklı kadrolarda çalışan kamu çalışanlarının görüşleri arasında anlamlı bir fark görülmemiştir. 
Tablo 11:Kamu çalışanlarının kariyer memnuniyeti ve iş doyumunu kendilerini tanımlama değişkenine göre karşılaştıran tek yönlü anova testi sonuçları

\begin{tabular}{|c|c|c|c|c|c|c|c|}
\hline & Kendini Tanımlama & $\mathrm{N}$ & ORT & SS & $\mathrm{F}$ & $\mathrm{P}$ & Fark \\
\hline \multirow{4}{*}{$\begin{array}{l}\text { Kariyer } \\
\text { Memnuniyeti }\end{array}$} & Sessiz sakin & 56 & 2,78 & 0,50 & \multirow{4}{*}{0,354} & \multirow{4}{*}{0,787} & \\
\hline & Sosyal ve dışa dönük & 89 & 2,84 & 0,39 & & & \\
\hline & Hiperaktif (hareketli) & 39 & 2,84 & 0,40 & & & \\
\hline & $\begin{array}{l}\text { Sinirli ve çabuk } \\
\text { parlayan }\end{array}$ & 18 & 2,87 & 0,36 & & & \\
\hline \multirow{4}{*}{ İş Doyumu } & Sessiz sakin & 56 & 2,94 & 0,39 & \multirow{4}{*}{1,975} & \multirow{4}{*}{0,119} & \\
\hline & Sosyal ve dışa dönük & 89 & 3,03 & 0,28 & & & \\
\hline & Hiperaktif (hareketli) & 39 & 2,94 & 0,34 & & & \\
\hline & $\begin{array}{l}\text { Sinirli ve çabuk } \\
\text { parlayan }\end{array}$ & 18 & 3,13 & 0,52 & & & \\
\hline \multirow{4}{*}{$\begin{array}{l}\text { Ücret ve diğer } \\
\text { haklar ve } \\
\text { ödemeler }\end{array}$} & Sessiz sakin & 56 & 2,84 & 0,60 & \multirow{4}{*}{0,284} & \multirow{4}{*}{0,837} & \\
\hline & Sosyal ve dışa dönük & 89 & 2,86 & 0,56 & & & \\
\hline & Hiperaktif (hareketli) & 39 & 2,85 & 0,54 & & & \\
\hline & $\begin{array}{l}\text { Sinirli ve çabuk } \\
\text { parlayan }\end{array}$ & 18 & 2,98 & 0,66 & & & \\
\hline \multirow{4}{*}{ Terfi } & Sessiz sakin & 56 & 2,65 & 0,82 & \multirow{4}{*}{2,702} & \multirow{4}{*}{0,047} & \\
\hline & Sosyal ve dışa dönük & 89 & 2,89 & 0,74 & & & \\
\hline & Hiperaktif (hareketli) & 39 & 2,56 & 0,79 & & & \\
\hline & $\begin{array}{l}\text { Sinirli ve çabuk } \\
\text { parlayan }\end{array}$ & 18 & 3,03 & 0,79 & & & \\
\hline \multirow{4}{*}{ Yönetici } & Sessiz sakin & 56 & 3,23 & 0,80 & \multirow{4}{*}{1,623} & \multirow{4}{*}{0,185} & \\
\hline & Sosyal ve dışa dönük & 89 & 3,13 & 0,71 & & & \\
\hline & Hiperaktif (hareketli) & 39 & 2,93 & 0,78 & & & \\
\hline & $\begin{array}{l}\text { Sinirli ve çabuk } \\
\text { parlayan }\end{array}$ & 18 & 3,33 & 0,88 & & & \\
\hline \multirow{4}{*}{$\begin{array}{l}\text { Takdir ve } \\
\text { ödüller }\end{array}$} & Sessiz sakin & 56 & 2,81 & 0,73 & \multirow{4}{*}{0,948} & \multirow{4}{*}{0,418} & \\
\hline & Sosyal ve dışa dönük & 89 & 2,99 & 0,69 & & & \\
\hline & Hiperaktif (hareketli) & 39 & 2,90 & 0,67 & & & \\
\hline & $\begin{array}{l}\text { Sinirli ve çabuk } \\
\text { parlayan }\end{array}$ & 18 & 3,03 & 0,73 & & & \\
\hline \multirow{4}{*}{$\begin{array}{l}\text { Faaliyet } \\
\text { prosedürleri }\end{array}$} & Sessiz sakin & 56 & 2,88 & 0,70 & \multirow{4}{*}{1,485} & \multirow{4}{*}{0,220} & \\
\hline & Sosyal ve dışa dönük & 89 & 3,08 & 0,66 & & & \\
\hline & Hiperaktif (hareketli) & 39 & 2,93 & 0,65 & & & \\
\hline & $\begin{array}{l}\text { Sinirli ve çabuk } \\
\text { parlayan }\end{array}$ & 18 & 2,83 & 0,70 & & & \\
\hline
\end{tabular}




\begin{tabular}{|c|c|c|c|c|c|c|c|}
\hline & Kendini Tanımlama & $\mathrm{N}$ & ORT & SS & $\mathrm{F}$ & $\mathrm{P}$ & Fark \\
\hline \multirow{4}{*}{ İş arkadaşları } & Sessiz sakin & 56 & 3,17 & 0,67 & \multirow{4}{*}{1,449} & \multirow{4}{*}{0,230} & \\
\hline & Sosyal ve dişa dönük & 89 & 2,99 & 0,73 & & & \\
\hline & Hiperaktif (hareketli) & 39 & 3,21 & 0,71 & & & \\
\hline & $\begin{array}{l}\text { Sinirli ve çabuk } \\
\text { parlayan }\end{array}$ & 18 & 3,25 & 0,72 & & & \\
\hline \multirow{4}{*}{ İşin doğası } & Sessiz sakin & 56 & 3,06 & 0,71 & \multirow{4}{*}{1,203} & \multirow{4}{*}{0,310} & \\
\hline & Sosyal ve dişa dönük & 89 & 3,12 & 0,66 & & & \\
\hline & Hiperaktif (hareketli) & 39 & 2,88 & 0,58 & & & \\
\hline & $\begin{array}{l}\text { Sinirli ve çabuk } \\
\text { parlayan }\end{array}$ & 18 & 3,14 & 0,77 & & & \\
\hline \multirow{4}{*}{ İletişim } & Sessiz sakin & 56 & 2,88 & 0,83 & \multirow{4}{*}{4,152} & \multirow{4}{*}{$0,007^{* *}$} & \multirow{4}{*}{$1-4$} \\
\hline & Sosyal ve dışa dönük & 89 & 3,14 & 0,64 & & & \\
\hline & Hiperaktif (hareketli) & 39 & 3,25 & 0,67 & & & \\
\hline & $\begin{array}{l}\text { Sinirli ve çabuk } \\
\text { parlayan }\end{array}$ & 18 & 3,47 & 0,71 & & & \\
\hline
\end{tabular}

${ }^{* *} P<0,05$ düzeyinde anlamlı fark ifade etmektedir.

Araştırmaya katılan kamu çalışanlarının kariyer memnuniyeti ve iş doyumu düzeylerini kendilerini tanımlama değișkenine göre değerlendirdiğimiz Tek Yönlü Anova testi analiz sonuçları Tablo 11 'de verilmiştir. Yapılan tek yönlü anova testi sonuçlarına göre iş doyumu ölçeğinin iletişim boyutu için kendini sinirli ve çabuk parlayan olarak tanımlayan kamu çalışanlarının düzeylerinin $(x=3,47 \pm 0,71)$ kendini sessiz ve sakin olarak tanımlayan çalışanlara göre $(x=2,88 \pm 0,83)$ anlamlı bir şekilde daha yüksek olduğu görülmüştür $(p<0,05)$.

Tablo 12. Kamu çalışanlarının kariyer memnuniyeti ve iş doyumunu eğitim durumu değişkenine göre karşılaştıran tek yönlü anova testi sonuçları

\begin{tabular}{|c|c|c|c|c|c|c|c|}
\hline & Eğitim Durumu & $\mathrm{N}$ & ORT & SS & $\mathrm{F}$ & $\mathrm{P}$ & Fark \\
\hline \multirow{3}{*}{$\begin{array}{l}\text { Kariyer } \\
\text { Memnuniyeti }\end{array}$} & Lise ve öncesi & 20 & 2,95 & 0,45 & \multirow{3}{*}{1,062} & \multirow{3}{*}{0,348} & \\
\hline & Lisans & 142 & 2,81 & 0,42 & & & \\
\hline & Lisansüstü & 40 & 2,80 & 0,43 & & & \\
\hline \multirow{3}{*}{ İş Doyumu } & Lise ve öncesi & 20 & 3,00 & 0,19 & \multirow{3}{*}{0,006} & \multirow{3}{*}{0,994} & \\
\hline & Lisans & 142 & 2,99 & 0,36 & & & \\
\hline & Lisansüstü & 40 & 2,99 & 0,39 & & & \\
\hline \multirow{3}{*}{$\begin{array}{l}\text { Ücret ve diğer } \\
\text { haklar ve } \\
\text { ödemeler }\end{array}$} & Lise ve öncesi & 20 & 2,85 & 0,49 & \multirow{3}{*}{0,008} & \multirow{3}{*}{0,992} & \\
\hline & Lisans & 142 & 2,87 & 0,58 & & & \\
\hline & Lisansüstü & 40 & 2,86 & 0,59 & & & \\
\hline
\end{tabular}


Kamu Çalışanlarının Kariyer Memnuniyetlerinin İş Doyumu Üzerine Etkisi

\begin{tabular}{|c|c|c|c|c|c|c|c|}
\hline & Eğitim Durumu & $\mathrm{N}$ & ORT & SS & $\mathrm{F}$ & $\mathrm{P}$ & Fark \\
\hline \multirow{3}{*}{ Terfi } & Lise ve öncesi & 20 & 3,06 & 0,69 & \multirow{3}{*}{1,786} & \multirow{3}{*}{0,170} & \\
\hline & Lisans & 142 & 2,76 & 0,75 & & & \\
\hline & Lisansüstü & 40 & 2,66 & 0,94 & & & \\
\hline \multirow{3}{*}{ Yönetici } & Lise ve öncesi & 20 & 3,06 & 0,63 & \multirow{3}{*}{0,117} & \multirow{3}{*}{0,889} & \\
\hline & Lisans & 142 & 3,15 & 0,79 & & & \\
\hline & Lisansüstü & 40 & 3,13 & 0,76 & & & \\
\hline \multirow{3}{*}{ Takdir ve ödüller } & Lise ve öncesi & 20 & 3,18 & 0,80 & \multirow{3}{*}{1,595} & \multirow{3}{*}{0,206} & \\
\hline & Lisans & 142 & 2,92 & 0,70 & & & \\
\hline & Lisansüstü & 40 & 2,84 & 0,66 & & & \\
\hline \multirow{3}{*}{$\begin{array}{l}\text { Faaliyet } \\
\text { prosedürleri }\end{array}$} & Lise ve öncesi & 20 & 3,16 & 0,71 & \multirow{3}{*}{0,890} & \multirow{3}{*}{0,412} & \\
\hline & Lisans & 142 & 2,96 & 0,66 & & & \\
\hline & Lisansüstü & 40 & 2,94 & 0,69 & & & \\
\hline \multirow{3}{*}{ İş arkadaşları } & Lise ve öncesi & 20 & 2,75 & 0,61 & \multirow{3}{*}{3,423} & \multirow{3}{*}{$0,035^{* *}$} & \multirow{3}{*}{$1-3$} \\
\hline & Lisans & 142 & 3,11 & 0,67 & & & \\
\hline & Lisansüstü & 40 & 3,25 & 0,84 & & & \\
\hline \multirow{3}{*}{ İşin doğası } & Lise ve öncesi & 20 & 2,96 & 0,67 & \multirow{3}{*}{0,366} & \multirow{3}{*}{0,694} & \\
\hline & Lisans & 142 & 3,06 & 0,66 & & & \\
\hline & Lisansüstü & 40 & 3,12 & 0,71 & & & \\
\hline \multirow{3}{*}{ İletişim } & Lise ve öncesi & 20 & 2,99 & 0,38 & \multirow{3}{*}{0,354} & \multirow{3}{*}{0,702} & \\
\hline & Lisans & 142 & 3,13 & 0,74 & & & \\
\hline & Lisansüstü & 40 & 3,14 & 0,80 & & & \\
\hline
\end{tabular}

** $P<0,05$ düzeyinde anlaml fark ifade etmektedir.

Araştırmaya katılan kamu çalışanlarının kariyer memnuniyeti ve iş doyumu düzeylerini eğitim durumu değişkenine göre değerlendirdiğimiz Tek Yönlü Anova testi analiz sonuçları Tablo 12'de verilmiştir. Yapılan tek yönlü anova testi sonuçlarına göre iş doyumu ölçeğinin iş arkadaşları boyutu için lisansüstü eğitim mezunu olan kamu çalışanlarının düzeylerinin $(x=3,25 \pm 0,84)$ lise ve önceki eğitim mezunu olan çalışanlara göre $(x=2,75 \pm 0,61)$ anlamlı bir şekilde daha yüksek olduğu görülmüștür $(\mathrm{p}<0,05)$.

\section{Sonuç ve Değerlendirme}

Araştırmaya katılan kamu çalışanlarının \%33,2'si 24-29 yaş, \%35,6'sı 30-35 yaş arası olup katılımcıların çoğunun genç olduğunu söyleyebiliriz. Katılımclların \%45,0'i kadın, \%55,0'i erkektir. Hizmet sürelerine bakıldığında \%47,5'i 2-5 yıl, \%20,8'i 6-10 yıl arası hizmete sahiptir. Araştırmaya katılan kamu çalışanlarının \%38,1'i boş zamanlarında kitap okuduğunu belirtmiş olup diğer seçenekler birbirine yakın orandadır. Katılımcıların \%61,4'ü sözleşmeli, \%20 ,3'ü memur veya uzman olarak çalışmaktadır. Günlük hayatta kendilerini 
nasıl tanımladıklarına bakıldığında \%44,1'i kendini sosyal ve dışa dönük olarak, \%27,7'si sessiz sakin olarak tanımlamaktadır. Araştırmaya katılanların \%70,3'lük bir çoğunluğu lisans mezunu, \%19,8'i lisansüstü eğitim mezunudur. Kamu çalışanlarının kariyer memnuniyeti ve iş doyumu ölçeklerine verdikleri cevaplara göre elde edilen ortalama puanlar ve standart sapma değerleri kariyer memnuniyeti ölçeği genel ortalama puanlarına göre araştırmaya katılan kamu çalışanlarının kariyer memnuniyeti düzeyinin orta seviyede olduğunu söyleyebiliriz. Buna göre kamu çalışanlarının iş doyumu düzeylerinin de orta seviyede olduğunu söyleyebiliriz. İș doyumu ölçeğinin tüm alt boyutlarında da birbirine yakın değerler ile orta düzeyde bir iş doyumu olduğu görülmektedir. Kamu çalışanlarının kariyer memnuniyeti ile iş doyumu düzeyleri arasındaki ilişkiyi belirlemek için yapılan korelasyon analizine göre kamu çalışanlarının kariyer memnuniyeti düzeyi ile iş doyumu düzeyleri arasında pozitif yönde zayıf bir ilişki bulunduğu görülmektedir. İ̧ doyumu ölçeğinin alt boyutlarına bakıldığında ise; kariyer memnuniyeti ile ücret ve diğer haklar ve ödemeler boyutu arasında pozitif yönde çok zayıf bir ilişki, terfi boyutu arasında pozitif yönde zayıf bir ilişki, yönetici boyutu arasında pozitif yönde çok zayıf bir ilişki, takdir ve ödüller boyutu arasında pozitif yönde zayıf bir iliş̧ki, işin doğası boyutu arasında pozitif yönde çok zayıf bir ilişki ve iletişim boyutu arasında pozitif yönde zayıf bir iliş̧i bulunduğu görülmektedir. Kamu çalışanlarının kariyer memnuniyeti ve iş doyumu düzeylerini cinsiyet değişkenine göre değerlendirdiğimiz T testi analiz sonuçlarına göre kariyer memnuniyeti ölçeğinde kadın ve erkek katılımcılar arasında anlamlı bir fark görülmemiştir. Küçük (2014), Akdeniz Üniversitesi Hastanesinde çalışan laboratuvar teknikerleri üzerinde yapmış olduğu çalışmada "yaş, eğitim seviyesi, cinsiyet değişkenlerine göre iş doyumları düzeyleri için belirleyici bir faktör olmadığı" sonucuna ulaşmıştır. Öztürk \& Şahbudak (2015), akademisyenler üzerine yaptıkları çalışmalarında "cinsiyete göre iş doyum düzeyinin gruplar arasında farklılık oluşturmadığı tespit edildiği" sonucuna ulaşmışlardır. Kamu çalışanlarının iş doyumlarına bakıldığında ise kadın çalışanların iş doyumu düzeylerinin erkek çalışanlara göre anlamlı bir şekilde daha yüksek olduğu görülmüştür. Orhaner Gündüz (2016), yaptığı araştırma sonucuna göre "cinsiyet duruma göre iş doyumu farklılığı gözlenmediği" sonucuna ulaşmıștır. Alt boyutlara bakıldığında da; ücret ve diğer haklar ve ödemeler konusunda kadın çalışanların düzeylerinin erkek çalışanlara göre daha yüksek olduğu, yönetici boyutunda kadın çalışanların düzeylerinin erkek çalışanlara göre daha yüksek olduğu, takdir ve ödüller boyutunda yine kadın çalışanların düzeylerinin erkek çalışanlara göre daha yüksek olduğu ve iş arkadaşları boyutunda da kadın çalışanların düzeylerinin erkek çalışanlara göre daha yüksek olduğu belirlenmiştir. Kamu çalışanlarının kariyer memnuniyeti ve iş doyumu düzeylerini yaş değişkenine göre değerlendirdiğimiz Tek Yönlü Anova testi analiz sonuçlarına göre kamu çalışanlarının kariyer memnuniyeti ve iş doyumu düzeylerinde yaş grupları arasında anlamlı farklar görülmüştür. Kariyer memnuniyeti ölçeğinde 24-29 yaş grubu çalışanların 
ve 36-40 yaş grubu çalışanların düzeylerinin 41 yaş üzerindeki çalışanlara göre anlamlı bir şekilde daha yüksek olduğu görülmüştür. Aynı şekilde iş doyumu ölçeğinde de 24-29 yaş grubu çalışanların ve 36-40 yaş grubu çalışanların düzeylerinin 41 yaş üzerindeki çalışanlara göre anlamlı bir şekilde daha yüksek olduğu görülmüştür. Mutlu (2020), otel çalışanları üzerine yaptığı çalışmada, çalışmamızda ulaştığımız sonuçlar dışında "yaş grupları ile kariyer memnuniyeti arasındaki ilişkilerin farklılaşmadığı” sonucuna ulaşmıştır. Elde edilen bu verilere göre genç yaş gruplarındaki kamu çalışanlarının kariyer memnuniyeti ve iş doyumu düzeylerinin 40 yaş üzeri çalışanlara göre daha yüksek olduğunu söyleyebiliriz. Kamu çalışanlarının kariyer memnuniyeti ve iş doyumu düzeylerini hizmet süresi değişkenine göre değerlendirdiğimiz Tek Yönlü Anova testi analiz sonuçlarına göre kamu çalışanlarının kariyer memnuniyeti düzeylerinde gruplar arasında anlamlı bir fark görülmemiștir. Boyar \& Güngörmüş (2016), muhasebe meslek mensupları üzerine yaptıkları çalışmada "kariyerinden memnun olan muhasebe meslek mensuplarının UFRS değerleme ölçülerine yönelik bilgi düzeyleri arasında pozitif yönde bir ilişki tespit edildiği" sonucuna ulaşarak araștırmamızdaki bulgulardan farklı sonuçları ortaya koymuşlardır. İş doyumu ölçeğine bakıldığında hizmet süresi 2-5 yıl arasında olan kamu çalışanlarının düzeylerinin hizmet süresi 16 yıl ve üzeri olan çalışanlara göre anlamlı bir şekilde daha yüksek olduğu görülmüştür. İş doyumu ölçeğinin alt boyutlarına bakıldığında ise terfi boyutu için hizmet süresi 2-5 yıl olan kamu çalışanlarının ve hizmet süresi 11-15 yıl olan çalışanların düzeylerinin hizmet süresi 16 yıl ve üzeri olan gruba göre anlamlı bir şekilde daha yüksek olduğu görülmüştür. Faaliyet prosedürleri boyutunda da hizmet süresi 0-1 yıl olan kamu çalışanlarının ve hizmet süresi 2-5 yıl olan çalışanların düzeylerinin hizmet süresi 16 yıl ve üzeri olan gruba göre anlamlı bir şekilde daha yüksek olduğu görülmüştür. Kamu çalışanlarının kariyer memnuniyeti ve iş doyumu düzeylerini boş zaman değerlendirme değişkenine göre değerlendirdiğimiz Tek Yönlü Anova testi sonuçlarına göre boş zamanımda kitap okurum diyen kamu çalışanlarının kariyer memnuniyeti düzeyleri boş zamanımda eğlence mekânlarına giderim diyen çalışanlara göre anlamlı bir şekilde daha yüksek görülmüştür. İş doyumu ölçeğinin alt boyutlarından işin doğası boyutu için de boş zamanımda kitap okurum diyen kamu çalıșanlarının iş doyumu düzeyleri boş zamanımda eğlence mekânlarına giderim diyen çalışanlara göre anlamlı bir şekilde daha yüksek görülmüştür. Kamu çalışanlarının kariyer memnuniyeti ve iş doyumu düzeylerini kadro değişkenine göre değerlendirdiğimiz Tek Yönlü Anova testi analiz sonuçlarına göre farklı kadrolarda çalışan kamu çalışanlarının görüşleri arasında anlamlı bir fark görülmemiştir. Kamu çalışanlarının kariyer memnuniyeti ve iş doyumu düzeylerini kendilerini tanımlama değişkenine göre değerlendirdiğimiz Tek Yönlü Anova testi analiz sonuçlarına göre iş doyumu ölçeğinin iletişim boyutu için kendini sinirli ve çabuk parlayan olarak tanımlayan kamu çalışanlarının düzeylerinin kendini sessiz ve sakin olarak tanımlayan çalışanlara göre anlamlı bir şekilde daha yüksek olduğu görülmüştür. Kamu 
çalışanlarının kariyer memnuniyeti ve iş doyumu düzeylerini eğitim durumu değişkenine göre değerlendirdiğimiz Tek Yönlü Anova testi analiz sonuçlarına göre iş doyumu ölçeğinin iş arkadaşları boyutu için lisansüstü eğitim mezunu olan kamu çalışanlarının düzeylerinin lise ve önceki eğitim mezunu olan çalışanlara göre anlamlı bir şekilde daha yüksek olduğu görülmüştür.

\section{Kaynakça}

Aktaş H. (2014). Kariyer Safhaları ve Demografik Değișkenler Bağlamında Kariyer Memnuniyeti ve Meslekî Bağlılık İlişkisi: Büro Yöneticileri, Yönetici Asistanları ve Sekreterler Üzerinde Bir Araștırma. The Journal of Academic Social Science Studies,26(1); 195-212.DOI:10.9761/JASSS2236

Avşaroğlu S., Deniz M.E., \& Kahraman A. (2005). Teknik Öğretmenlerde Yaşam Doyumu İș Doyumu ve Mesleki Tükenmişlik Düzeylerinin İncelenmesi. Selçuk Üniversitesi Sosyal Bilimler Enstitüsü Dergisi, 14(1): 115-129.

Boyar E. \& Güngörmüş A.H. (2016). Muhasebe Meslek Mensuplarının Proaktif Kişilik Özelliklerinin, Kariyer Memnuniyeti İle UFRS’ ye Bakış Açıları ve Bilgi Düzeyleri Üzerine Etkisi. Muhasebe ve Finansman Dergisi,70(1):55-66.

Çankaya M. (2020). Kadın Sağlık Çalışanlarında Kültürel Değerler ile Kariyer Bağlılığı Arasındaki İlişkide Kariyer Memnuniyetinin Aracılık Rolü. Turkish Studies - Social Sciences, 15(4): 1779-1804.

Çarıkcı, İ. \& Oksay, A. (2004). Örgütsel Yapı ve Meslek Farklılıklarının İş Tatmini Üzerindeki Etkileri. Hastane Çalışanları Üzerine Bir Araştırma. Süleyman Demirel Üniversitesi Íktisadi ve İdari Bilimler Fakültesi Dergisi, 9 (2), 157-172.

Çelik M. (2012). Konaklama İşletmelerinde Algılanan Örgütsel Adaletin Yenilikçi Davranışa Etkisinde Kariyer Memnuniyetinin Aracılık Etkisi. İss, Güç Endüstri İliş̧kileri ve İnsan Kaynakları Dergisi, Cilt 14(2): 99-122.

Çetin C. (2009). Insan Kaynaklarının Eğitimi ve Geliştirilmesi. 1. Baskı, Beta Basım Yayın Dağıtım, İstanbul.

Dikmen A.A. (1995). İș Doyumu ve Yaşam Doyumu İlișkisi. Ankara Üniversitesi SBF Dergisi, 50(3): 115-140. DOI: 10.1501/SBFder_0000001851

Eğinli A.T. (2009). Çalışanlarda İş Doyumu: Kamu ve Özel Sektör Çalışanlarının İş Doyumuna Yönelik Bir Araştırma. Atatürk Üniversitesi İktisadi ve İdari Bilimler Dergisi, 23(3): 35- 52 .

Durmuş S. \& Günay O. (2007). Hemşirelerde İş Doyumu ve Anksiyete Düzeyini Etkileyen Faktörler. Erciyes Tıp Dergisi (Erciyes Medical Journal), 29(2): 139-146.

Greenhaus J.H., Parasuraman S.\& Wormly W.M. (1990). Effects of Race on Organizational Experiences, Job Performance Evaluations, and Career Outcomes. Academy of Management Journal, 33(1): 64-86.

Judge T.A., Cable D.M., Boudreau J.W. \& Bretz R.D. (1994), An Empirical Investigation of The Predictors of Executive Career Success, Center forAdvanced Human Resource 
Studies, School of Industrial and Labor Relations,Cornell University, Ithaca, New York.

Judge T.A., Cable D.M., Boudreau J.W.\& Bretz R.D.(1995). An Empirical Investigation of The Predictorsof Executive Career Success. Personnel Psychology, 48(3): 485-519.

Küçük S. (2014). Sağlık Çalışanlarında İş Doyumu ve İş Doyumunu Etkileyen Stres Faktörleri (Akdeniz Üniversitesi Hastanesi Laboratuvar Teknikerleri Örneği), (Yayınlanmamış Yüksek Lisans Tezi), Beykent Üniversitesi Sosyal Bilimler Enstitüsü.

Lepnurm R, Dobson R, Backman A, \& Keegan D. (2006). Factors Explaining Career Satisfaction Among Psychiatristsand Surgeons in Canada, Can J Psychiatry,51(4):243-255.

Mecek M. (2020).Kamu Görevlilerinin Ayrıldıkları Kuruma Karşı Görev Alma Yasağı: Kapsam ve Uygulaması. Journal of Social and Humanities Sciences Research, 7 (63): 3978-3990.

Musal B., Elçi Ö.Ç., \& Ergin S. (1995). Uzman Hekimlerde Mesleki Doyum. Toplum ve Hekim, 10(68): 2-7.

Mutlu H. (2020). Kariyer Gelişiminin Kariyer Bağlılığı ve Kariyer Memnuniyeti Üzerindeki Etkileri: Otel Çalıșanları Üzerinde Bir Araștırma, (Yayınlanmamıș Yüksek Lisans Tezi), Süleyman Demirel Üniversitesi Sosyal Bilimler Enstitüsü.

Nunnaly J.C. (1978). Psychometric theory, 2nd edn. McGraw-Hill. New York.

Orhaner Gündüz G.(2015. Banka Çalışanlarında İș Doyumu ve İș Doyumunun Örgütsel Bağlılığa Etkisi, (Yayınlanmamış Yüksek Lisans Tezi), Gazi Üniversitesi Eğitim Bilimleri Enstitüsü.

Öztürk M. \& Şahbudak E.(2015). Akademisyenlikte İş Doyumu. Uluslararası Sosyal Araştırmalar Dergisi, 8(40): 494-501.

Paksoy M.H. (2007). Üniversitelerde Akademik Personelin İș Memnuniyeti: Harran Üniversitesi Örneği. Selçuk Üniversitesi Karaman İ.I.B.F. Dergisi, 9(12): 138-151.

Şencan, N.S. (2011). Türk İlaç Sanayinde Çalışan Yöneticilerin Örgütsel Bağlllık ve Iş̧ Doyumlarına Yönelik Bir Araştırma.(Yayınlanmamıș Doktora Tezi), Hacettepe Üniversitesi, Sağlık Bilimleri Enstitüsü.

Telman N. \& Ünsal P. (2004). Çalışan Memnuniyeti,Epsilon Yayınevi, İstanbul.

Yelboğa A. (2009). Validity and Reliability of The Turkish Version of The Job Satisfaction Survey (JSS).World Applied Sciences Journal, 6(8): 1066-1072. 